\title{
Isolation and Antimicrobial Resistance Profiles of Enterobacteria from Nestling Grey-Breasted Parakeets (Pyrrhura Griseipectus)
}

-Author(s)
Machado DN'
Lopes ES'
Albuquerque AH'
Horn RV"
Bezerra WGA'
Siqueira RAS'
Lopes IT"
Nunes FP"
Teixeira RSC'
Cardoso WM'
I Laboratório de Estudos Ornitológicos,
Programa de Pós-graduação em Ciências
Veterinárias, Faculdade de Veterinária,
Universidade Estadual do Ceará (UECE),
Brazil.
" Projeto Periquito Cara-suja, AQUASIS,
Caucaia, CE, Brazil.

\section{Mail Address}

Corresponding author e-mail address William Cardoso Maciel

Alphaville Eusébio, Rodovia CE-040, Km 22, Pires Façanha / Cep 61.760-903,

Eusébio-CE

Email: william.maciel@ymail.com

\section{-Keywords}

Bacterial resistance, E.coli, Psittacine, Wild birds

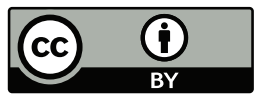

Submitted: 22/May/2017

Approved: 08/September/2017

\section{ABSTRACT}

The psittacine Pyrrhura griseipectus is a threatened species currently only found in Ceará State, Brazil. A microbiological survey was conducted to determine the composition of the enteric microbiota of this species, as well as the phenotypic profiles of antimicrobial susceptibility presented by the isolates. Cloacal swabs were collected from individual birds and submitted to microbiological processing. Antimicrobial susceptibility profiles were evaluated using the disk diffusion method. Bacteria of the genus Escherichia, Proteus, Citrobacter, Pantoea, Klebsiella, Enterobacter, Morganella, Hafnia, Enterobacter, and Serratia were isolated. The most frequently isolated species were Escherichia coli, Proteus mirabilis and Proteus vulgaris, corresponding to $36.1 \%$, $26.4 \%$, and $8.3 \%$, respectively. Isolates were more frequently resistant to azithromycin and tetracycline, while Escherichia coli was the main species presenting multidrug resistance. In conclusion, free-living greybreasted parakeets may harbor enterobacteria with high antimicrobial resistance rates

\section{INTRODUCTION}

Bacterial resistance to antibiotics has been extensively studied as it is a matter of health concern and of its commercial implications. Studies have shown the increasing role of free-living birds as hosts for bacteria that carry antibiotic-resistance mechanisms (Smith et al., 2014; Carroll et al., 2015). Therefore, these animals are considered important agents for the emergence of multidrug resistance in several environments around the world, (Hasan et al., 2012) as well as for the spreading of resistant bacteria to multiple hosts and places.

It is known that Psittaciformes are capable of harboring numerous emerging zoonotic pathogens, as well as dispersing infected arthropod vectors (Godoy, 2007). Thus, the presence of Gram-negative bacteria, including those belonging to the Enterobacteriaceae family, in their intestinal microbiota has been considered an indication of potential diseases (Bangert et al., 1988; Mattes et al., 2005). Currently, microbiological studies with psittacine have increasingly isolated enterobacteria in healthy birds (Serafini et al., 2015; Lopes et al., 2015; Machado et al., 2016), which may indicate a more opportunistic role of these agents (Hidasi et al., 2013).

Among the enterobacteria relevant to both human and animal health, the role of the bacterium Escherichia coli (E. coli) as a potential pathogenic agent has been emphasized. E. coli is a commensal resident of microbiota of animals and humans (Schremmer et al.,1999); however, pathogenic strains are responsible for numerous intestinal and extraintestinal diseases in both domestic and wild birds (Marietto-Gonçalves et al., 2007). The genus Salmonella is also considered a major zoonotic 
Machado DN, Lopes ES, Albuquerque AH, Horn RV, Bezerra WGA, Siqueira RAS, Lopes IT, Nunes FP, Teixeira RSC, Cardoso WM
Isolation and Antimicrobial Resistance Profiles of Enterobacteria from Nestling Grey-Breasted Parakeets (Pyrrhura Griseipectus) agent, responsible for foodborne infections, especially from poultry products (Tortora et al., 2012).

The composition of the enteric microbiota of wild life psittacines is not fully known. In addition, few studies have been conducted with native Brazilian psittacines, emphasizing the importance of research focusing on these species (Alves et al., 2013; Vaz et al., 2017), and therefore, the Pyrrhura griseipectus (Salvadori, 1900), an endemic bird from the Northeast region of Brazil, was chosen as the object of this study. It is found in three areas of the state of Ceará: Ibaretama, Quixadá, and the Baturité Massif (Girão et al., 2010). Although this species, which common name is greybreasted parakeet, has been recently adapted to breed in artificial nests, it builds nests in cavities inside tree trunks in the wild.

The grey-breasted parakeet is currently categorized as an endangered species (Sigrist, 2014, Brasil, 2014) due to its high vulnerability to human activities, particularly those related to illegal wildlife trade and urban expansion. Therefore, research on the composition of their intestinal microbiota, including the presence of bacteria with antimicrobial resistance, are important as the results may be used as tools to assist in the conservation of these birds (Prioste et al., 2013). The present study investigated the presence of enterobacteria in wild juvenile grey-breasted parakeets found in artificial nests. Also, the response of these agents to several antibiotics was analyzed.

\section{MATERIAL AND METHODS}

\section{Study area}

The environment of Baturité Massif $\left(4^{\circ} 16^{\prime} S\right.$, $38^{\circ} 56^{\prime} \mathrm{W}$ ), located approximately $100 \mathrm{~km}$ from Fortaleza (capital city of Ceará State, Brazil), consists of moist forests in the midst of a dry and warm region, and it is an Environmental Protection Area (EPA). With an altitude of 600 meters in some areas, the EPA of Baturite Massif includes the municipalities of Aratuba, Baturité, Capistrano, Guaramiranga, Mulungu, Pacoti, Caridade, and Redenção.

\section{Sampling}

This study was authorized by the Brazilian agency for the environment and natural renewable resources (Instituto Brasileiro do Meio Ambiente e dos Recursos Naturais Renováveis, IBAMA) under SISBIO protocol $n$. 37211334, and approved by the Local Ethics Committee for the Use of Animals of the State University of Ceará (Protocol 4832011/14).
In order to contribute for the conservation of this species, artificial nests made of wood were placed inside private properties nearby the natural habitat of the parakeets. The nests are part of the conservation program of this species promoted by the nongovernmental organization Associação de Pesquisa e Presevação de Ecossistemas Aquáticos (AQUASIS). Sampling was conducted during the reproductive period of the species, which occurs in the rainy season in Ceará State, from February to May in 2014 and again in 2015. A total of 79 healthy juvenile greybreasted parakeets, with approximately 2 to 3 weeks of age were selected, and sampled for intestinal microbiota analysis. The birds were removed from the artificial nests, and carefully physically restrained to reduce stress as much as possible (Godoy, 2007). Birds were individually identified with leg bands and then submitted to the sampling procedure by using individual sterile cloacal swabs to obtain the fecal material. After sampling, individuals were promptly returned to the nests.

The cloacal swab samples were placed in tubes containing buffered peptone water broth, and maintained in a box containing ice in order to preserve their intrinsic properties. The collected material was transported to the Laboratório de Estudos Ornitológicos (LABEO) of the Universidade Estadual do Ceará, for microbiological analysis.

\section{Microbiological analysis}

The samples stored in tubes containing buffered peptone water were removed from the ice box and incubated in a bacteriological incubator at $37^{\circ} \mathrm{C}$ for 24 $\mathrm{h}$, which were the temperature and duration applied in all analytical procedures in this study. After this step, $1-\mathrm{mL}$ aliquots of the initial samples were transferred to tubes containing selenite cystine broth or brain heart infusion broth, and incubated again (Lopes et al., 2015). A loopful of each broth was streaked on MacConkey agar enteric and Hektoen agar plates, and incubated. One to three bacterial colonies from each sample were selected according to the morphological characteristics presented in each selective media (Lopes et al., 2015).

The isolates were submitted to the following biochemical tests for the bacterial identification: investigation of classic fermentation characteristics in TSI (Triple-Sugar-Iron) agar, decarboxylation reactions in LIA (Lysine Iron agar), production of sulfide and indole and motility in SIM medium, and biochemical activities in methyl red and Voges-Proskauer tests, ornithine 
Machado DN, Lopes ES, Albuquerque AH, Horn RV, Bezerra WGA, Siqueira RAS, Lopes IT, Nunes FP, Teixeira RSC, Cardoso WM
Isolation and Antimicrobial Resistance Profiles of Enterobacteria from Nestling Grey-Breasted Parakeets (Pyrrhura Griseipectus) decarboxylase, mannitol, arabinose, raffinose, dulcitol, adonitol, inositol, urease, rhamnose, citrate, malonate, glucose and lactosere actions (Koneman et al., 2010)

The presence of $E$. coli species was confirmed both by the classical biochemical profile shown and by the metallic green sheen that indicates this bacterial growth in Eosin Methylene Blue (EMB) agar (Koneman et al., 2010). Samples with biochemical profile of the genus Salmonella were further investigated using the rapid agglutination test with sera anti-somatic " $O$ " (Lopes et al., 2015).

\section{Antimicrobial resistance}

The antimicrobial susceptibility test was performed using the disk diffusion method, using the standards provided by Clinical and Laboratory Standards Institute (CLSI, 2012). Antibiotics of the following classes were selected: aminoglycosides, cephalosporins, chloramphenicol, macrolides, polymyxins, quinolones, sulfonamides, tetracycline and trimethoprim. Therefore, discs containing the following antibiotics with respective concentrations were used: azithromycin $(15 \mu \mathrm{g})$, nalidixic acid $(30 \mu \mathrm{g})$, ciprofloxacin $(5 \mu \mathrm{g})$, chloramphenicol $(30 \mu \mathrm{g})$, streptomycin $(10 \mu \mathrm{g})$, gentamycin $(10 \mu \mathrm{g})$, tetracycline $(30 \mu \mathrm{g})$, ceftiofur $(30 \mu \mathrm{g})$, polymyxin $\mathrm{B}(300 \mu \mathrm{g})$, sulfamethoxazole and trimethoprim $(25 \mu \mathrm{g})$ and sulfonamide $(300 \mu \mathrm{g})$.

A suspension of the isolated bacteria was prepared by inoculating the pure colonies into sterile saline solution to reach inoculum turbidity equal a $0.5 \mathrm{McF}$ arland turbidity standard. The inocula were streaked on Mueller-Hinton agar plates, and the antibiotic discs containing the antimicrobial were placed on the plates, and incubated. After incubation, the results were interpreted by measuring the inhibition zones around the discs (Lopes et al., 2015). The strains that showed phenotypic resistance to three or more antibiotics were considered multidrug resistant. The E. coli strain ATCC 25922 was used as control sample.

\section{RESULTS}

A total of 144 strains were isolated, and belonged to the genera Escherichia, Proteus, Citrobacter, Pantoea, Klebsiella, Enterobacter, Morganella, Hafnia, Enterobacter, and Serratia. All birds were positive for at least one of the isolated bacteria. In addition, more than one species per fecal sample were detected in some cases.
The most frequently isolated species were: Escherichia coli, with 52 isolates (36.1\%), followed by Proteus mirabilis, with 38 isolates (26.4\%), Proteus vulgaris with 12 isolates (8.3\%), and Citrobacter freundii, with 10 isolates (6.9\%). The frequency of the other species ranged between 1 and 7 isolates, and no Salmonella sp. was isolated. The results are shown in Table 1.

Table 1 - Absolute numbers (n)and frequencies (\%) of bacterial isolates, and frequency of positive birds per isolate obtained in the 79 individual cloacal swab samples collected from Pyrrhura griseipectus nestlings in Ceará State, Brazil

\begin{tabular}{lccc}
\hline Bacterial isolates & Isolates & Positive birds & Frequency \\
\hline & $\mathrm{n}$ & $(\%)$ & $(\%)$ \\
\hline Escherichia coli & 52 & 65.8 & 36.1 \\
\hline Proteus mirabilis & 38 & 48.1 & 26.4 \\
\hline Proteus vulgaris & 12 & 15.2 & 8.3 \\
Citrobacter freundii & 10 & 12.7 & 6.9 \\
Pantoea agglomerans & 7 & 8.9 & 4.8 \\
Klebsiella pneumoniae & 6 & 7.6 & 4.2 \\
\hline Enterobacter aerogenes & 5 & 6.3 & 3.5 \\
Morganella morganii & 3 & 3.8 & 2.1 \\
Hafnia alvei & 2 & 2.5 & 1.4 \\
Enterobacter cloacae & 2 & 2.5 & 1.4 \\
Citrobacter amalonaticus & 2 & 2.5 & 1.4 \\
Citrobacter diversus & 2 & 2.5 & 1.4 \\
\hline Enterobacter sakazakii & 1 & 1.3 & 0.7 \\
Serratia liquefaciens & 1 & 1.3 & 0.7 \\
Serratia rubidae & 1 & 1.3 & 0.7 \\
\hline Total & 144 & - & 100.0 \\
\hline & & & \\
\hline
\end{tabular}

Out of the 144 bacterial isolates obtained, 141 were submitted to the antimicrobial susceptibility test, and three samples were not used due to conservation issues. Three of the antibiotic compounds tested showed low efficacy against the isolates: $38.3 \%, 18.4 \%$, and $13.5 \%$ of the isolates were resistant to azithromycin, tetracycline, and sulfonamide, respectively (Table 2).

The results in Table 2 show that, other than the species Serratia liquefaciens, Serratia rubidae and Enterobacter cloacae, the isolates presented variable resistance levels to 9 out of the 11 tested antibiotics; only ciprofloxacin and ceftiofur fully inhibited all of the tested strains. In this context, $21(14.9 \%)$ isolates presented multidrug resistance, with $E$. coli isolates as the most frequent, accounting for $33 \%$ of the isolates (7/21) and presenting resistance to azithromycin, chloramphenicol, sulfametoxazole+trimetropim, sulfonamide, and tetracycline, with a variation ranging from $8.2 \%$ to $28.6 \%$. 
Table 2 - Antibiotic resistance of enterobacteria isolated from Pyrrhura griseipectus nestlings of Ceará State, Brazil.

\begin{tabular}{lccccccccccccc}
\hline \multirow{2}{*}{ Species } & $\mathrm{AZI}$ & $\mathrm{POL}$ & $\mathrm{GEN}$ & $\mathrm{NAL}$ & $\mathrm{SUL}$ & $\mathrm{TET}$ & $\mathrm{CFT}$ & SUT & CLO & STR & CIP \\
\cline { 2 - 9 } & $\mathrm{n}(\%)$ & $\mathrm{n}(\%)$ & $\mathrm{n}(\%)$ & $\mathrm{n}(\%)$ & $\mathrm{n}(\%)$ & $\mathrm{n}(\%)$ & $\mathrm{n}(\%)$ & $\mathrm{n}(\%)$ & $\mathrm{n}(\%)$ & $\mathrm{n}(\%)$ & $\mathrm{n}(\%)$ \\
\hline Citrobacter amalonaticus & $1(50)$ & $1(50)$ & 0 & $1(50)$ & 0 & $1(50)$ & 0 & 0 & 0 & 0 & 0 \\
Citrobacter diversus & 0 & $1(50)$ & 0 & $1(50)$ & 0 & 0 & 0 & 0 & 0 & 0 & 0 \\
Citrobacter freundii & $5(50)$ & $7(70)$ & 0 & $1(10)$ & $1(10)$ & $5(50)$ & 0 & $1(10)$ & 0 & 0 & 0 \\
Enterobacter aerogenes & $2(40)$ & $1(20)$ & 0 & $1(20)$ & $1(20)$ & $2(40)$ & 0 & $1(20)$ & $1(20)$ & 0 & 0 \\
Enterobacter cloacae & 0 & 0 & 0 & 0 & 0 & 0 & 0 & 0 & 0 & 0 & 0 \\
Enterobacter sakazakii & 0 & 0 & 0 & $1(100)$ & 0 & 0 & 0 & 0 & 0 & 0 & 0 \\
Escherichia coli & $4(8.2)$ & $1(2.0)$ & $1(2.0)$ & $3(6.1)$ & $10(20.4)$ & $14(28.6)$ & 0 & $7(14.3)$ & $5(10.2)$ & $1(2.0)$ & 0 \\
Hafnia alvei & $1(50)$ & 0 & 0 & 0 & 0 & 0 & 0 & 0 & 0 & 0 \\
Klebsiella pneumoniae & $5(83.3)$ & 0 & 0 & $1(16.7)$ & 0 & 0 & 0 & 0 & 0 & $1(16.7)$ & 0 \\
Morganella morganii & $2(66.7)$ & $\mathrm{NR}$ & 0 & 33,3 & 33,3 & $3(100)$ & 0 & 0 & 0 & 0 \\
Pantoeae agglomerans & $2(28.6)$ & $1(14.3)$ & 0 & $1(14.3)$ & $1(14.3)$ & $1(14.3)$ & 0 & $2(28.6)$ & 0 & 0 \\
Proteus mirabilis & $25(65.8)$ & $\mathrm{NR}$ & $1(2.6)$ & $7(18.4)$ & $4(10.5)$ & $\mathrm{NR}$ & 0 & $5(13.1)$ & $2(5.2)$ & $4(10.5)$ & 0 \\
Proteus vulgaris & $7(58.3)$ & $\mathrm{NR}$ & 0 & $1(8.3)$ & $2(16.7)$ & $\mathrm{NR}$ & 0 & 0 & 0 & 0 \\
Serratia liquefaciens & 0 & 0 & 0 & 0 & 0 & 0 & 0 & 0 & 0 & 0 \\
Serratia rubidae & 0 & 0 & 0 & 0 & 0 & 0 & 0 & 0 & 0 & 0 \\
\hline Total (n=141) & $54(38.2)$ & $12(8.5)$ & $2(1.4)$ & $17(12.0)$ & $19(13.5)$ & $26(18.4)$ & 0 & $16(11.3)$ & $8(5.8)$ & $6(4.2)$ & 0 \\
\hline
\end{tabular}

AZl: Azithromycin, POL B: Polymycin B, GEN: Gentamycin, NAL: Nalidix acid, SUL: Sulfonamide, TET: Tetracycline, CTF: Ceftiofur, SUT: Sulfametoxazole + Trimetropim, CLO: Chloramphenicol, EST: Streptomycin, CIP: Ciprofloxacin, NR: Natural Resistance

The table 3 shows the resistance profiles of $E$. coli strains, the major representative of multidrug resistance. One strain was resistant to 9 antibiotics, while the other six presented resistance patterns from three to five antibiotics.

Table 3 - Multidrug resistant profiles of Escherichia coli strains isolated

\begin{tabular}{ll}
\hline Number of isolates & Multidrug Resistance Profiles \\
\hline 1 & AZI, POL,GEN,NAL,SUL,TET,SUT,CLO,STR \\
1 & NAL,SUL,TET,SUT,CLO \\
2 & SUL,TET,SUT \\
3 & SUL,TET,SUT,CLO \\
\hline Total: 7 &
\end{tabular}

SUL: Sulfonamide, TET: Tetracycline, AZI: Azithromycin, POL: Polymycin B, GEN: Gentamycin, NAL: Nalidixic acid, CLO: Chloramphenicol, STR: Streptomycin, SUT: Sulfametoxazole-trimetropim

\section{DISCUSSION}

There are few studies on the enteric bacterial microbiota of free-living birds, especially those associated with its development altricial birds. Therefore, to the best of the authors' knowledge, this is the first study developed to evaluate the enteric microbiota of the endangered species Pyrrhura griseipectus. This study provides new information that will help to fill knowledge gaps on the health of these birds in the wild.

The results show that $E$. coli as the most prevalent bacterium in the microbiota, in agreement with the literature reporting the presence of this bacterium in the microbiota of young and adult wild birds (Dongen et al., 2013). Hidasi et al. (2013) studied the intestinal microbiota of parrots belonging to different species (Psittaciformes) seized from illegal trade and also found that E. coli was the most prevalent species (33.8\%). Vaz et al. (2017) detected that $72.7 \%$ of wild redtailed Amazon parrot (Amazona brasilensis) nestlings sampled from artificial wooden nests harbored E. coli; however, the authors considered this result within the normal microbiological profile of such birds.

In the present study, E. coli and other enterobacteria may have had a commensal behavior at the time of sampling, because they were isolated from apparently healthy birds with no specific signs of bacterial disease (Szmolka \& Nagy, 2013). However, while E. coli strains may be part of the normal enteric microbiota, some pathogenic strains still may potentially induce virulence mechanisms, resulting colibacillosis, salpingitis, respiratory diseases, omphalitis, or septicemia (Godoy, 2007). In addition, E. coli populations in the bird's intestines are likely to trigger a virulence response when subjected to environmental changes or to oscillations of the host's immune system (Ewers et al., 2009).

The possibility of psittacines to harbor potentially pathogenic E. coli strains, while showing no overt clinical signs, is a relevant health concern as these birds may serve as asymptomatic reservoirs. The studies of Saidenberg et al. (2012) showed the presence of E. coli with virulence genes reported in cases of severe illness in clinically asymptomatic parrots. This indicates that these birds may suffer disease in a near future or may 
Machado DN, Lopes ES, Albuquerque AH, Horn RV, Bezerra WGA, Siqueira RAS, Lopes IT, Nunes FP, Teixeira RSC, Cardoso WM
Isolation and Antimicrobial Resistance Profiles of Enterobacteria from Nestling Grey-Breasted Parakeets (Pyrrhura Griseipectus) excrete this pathogen in the environment, potentially contaminating other animals.

The second most frequently isolated microorganisms in this study belong to the genus Proteus sp., and were represented by the species Proteus mirabilis and Proteus vulgaris. These bacilli were previously isolated in young birds, and it was identified that their population tends to decrease as the birds grow older (Naldo et al., 1998). It is considered an opportunistic microorganism, and upper respiratory system disorders and pododermatitis have been associated with infections by Proteus sp. in wild birds (Olinda et al., 2012).

Citrobacter freundii, considered as an opportunistic and ubiquitous bacteria (Fernandez et al. 2011), has been detected as the primary agent in cases of sudden death in captive parrots (Churria et al., 2014). Pantoea agglomerans is a potential human pathogen (Cruz et al., 2007) and it is commonly found in nature, especially in plants, water, soil, and animals (Delétoile et al., 2009). This suggests that free-living birds may acquire these bacteria from direct contact with leaves, water, or food particles found in their habitats (Gibbs et al., 2007).

Enterobacteria of the genera Klebsiella, Enterobacter, Morganella, Hafnia and Serratia were less frequently isolated in this study; however, their isolation in wild birds was previously reported in other studies (Gibbs et al., 2007; Santos et al., 2010). Those bacteria are responsible for occasional infections and, in some cases, can function as primary pathogens (Gerlach, 1994, Hidasi et al., 2013, Davies et al., 2016)

The absence of Salmonella was also observed in other Brazilian studies, with low detection rates in apparently healthy wild birds, whether maintained in captivity or in the wild (Allgayer et al., 2009; Santos et al., 2010; Lopes et al., 2015, Machado et al., 2016). Because psittacines are very sensitive to avian salmonellosis, particularly at young ages (MariettoGonçalves et al., 2010), the absence of Salmonella spp in the present study suggests that the evaluated birds were not exposed to any pathogen of this genus (Godoy, 2007). In addition, no dead parakeets were found in the present study to allow their evaluation.

Interestingly, Salmonella shedding is usually intermittent (Gerlach, 1994) and it is possible that an infected bird may not shed it at the time of sampling (Butron \& Brightsmith, 2010). Another possible explanation for the absence of Salmonella spp. in the present study may be the young age of the sampled parakeets, since enteric microbiota of birds gradually changes as they grow up (Kohl, 2012). Moreover,
Hidasi et al. (2013) state that Salmonella spp. are uncommon habitants of the microbiota of captive and wild life psittacines.

The enterobacteria detected in this research study is explained by the fact that young birds are colonized by microbes immediately after hatch, and acquire a microbial biomass by contact with environmental microorganisms, as well as by parental feeding, both of which considered the main sources of microbial transmission to developing birds (Mills et al., 1999). Moreover, the young birds may have acquired this harmful microbial load by direct contact with other animals that might have visited the artificial nests, such as mice, bats, and other avian species, or by indirect contact with their secretions (Allgayer et al., 2009; Serafini et al., 2015).

The recent interest in the study of the free-living birds stems from the perception that these birds may be carriers of antimicrobial resistance mechanisms, as the host species may acquire dangerous pathogens as well as disseminate them (Beskin et al., 2009). Although free-living birds have infrequent direct contact with antimicrobial agents, they are still capable to host resistant bacteria or to be infected by these microbes (Radhouani et al., 2012). Interestingly, the studied parakeets had direct contact with their parents in a reduced space in the artificial nests, which could facilitate a process of bacterial transmission between the birds and through the environment of the nests.

Greater resistance was primarily observed to azithromycin, followed by sulfonamide and nalidixic acid. The first is an important antibiotic of the macrolides class, and used in human and veterinary medicine for the treatment of infections caused by Gram-positive and Gram-negative bacteria (Mitchell, 2005). A significant resistance to this antibiotic has been detected in bacterial samples from psittacines seized from illegal trade, which may be explained by its inadequate use, as well as by the transmission of resistant clones (Lopes et al., 2015).

In addition, the detected resistance to tetracycline and sulfonamide, used both in human and veterinary medicine, may indicate a wide spread of resistant bacteria in different environments, as shown in previous studies with bacteria of animal origin (Hirsh \& Zee, 2009; Hu et al., 2013).

The isolation of antibiotic-resistant Enterobacter aerogenes, Klebsiella pneumoniae, Pantoea agglomerans, Proteus sp., and E. coli in the present study is a significant finding, as they may transmit resistance genes to different bacterial genera (Levinson, 2010), 
Machado DN, Lopes ES, Albuquerque AH, Horn RV, Bezerra WGA, Siqueira RAS, Lopes IT, Nunes FP, Teixeira RSC, Cardoso WM
Isolation and Antimicrobial Resistance Profiles of Enterobacteria from Nestling Grey-Breasted Parakeets (Pyrrhura Griseipectus) allowing the exchange of these genes between commensal bacteria and those with elevated pathogenic potential, which may persist for longer periods in the host's enteric microbiota.

Regarding the resistance results obtained from $E$. coli strains, previous studies have shown similar profiles in strains isolated from migratory birds. The research of Bonnedahl et al. (2009), for example, showed that $E$. coli isolated from juvenile seagulls presented significant rates of resistance to tetracycline. In addition, a study with wild birds in rehabilitation environments before their reintroduction in the wild performed by Hidasi et al. (2013) found E. coli strains with high levels of resistance to chloramphenicol (33.1\%), tetracycline $(69.1 \%)$ and sulfonamide $(71.5 \%)$. Both studies demonstrate that bacterial resistance may be related to direct or indirect exposure to human activity, and it is usually associated with selective pressure by antibiotics.

In this study, seven E. coli strains showed multidrug resistance, out of which one presented resistance to 9 of the 11 antibiotics tested. This phenomenon was previously demonstrated in other studies with freeliving birds, even in harsh environments with little human presence, as reported by Sjølund et al. (2008), who isolated multidrug resistant $E$. coli strains from the enteric microbiota of birds in the Arctic. This complex bacterial capacity to develop resistance mechanisms has been the focus of numerous studies, and frequently, one of the main challenges is to determine the origin of such resistant strains in wild animals, especially birds, whose ability of vast mobilization makes them capable of disseminating numerous microbes in various regions.

The resistant bacteria isolated in this study may also have been horizontally transmitted by the parents, which may have had contact with other animals or even with products of human origin (i.e., food leftovers and adverse secretions) due to the strong presence of private estates and tourist activities in the region where the studied birds were found. According to Nascimento et al. (2010), this region has experienced a significant human population growth in recent years, especially in urban areas, and are associated with the development of the construction industry and the tourism activities.

In this context, the increasing manipulation of birds and artificial boxes to monitor the birth and growth of fledglings may be a contamination source. Therefore, the use of adequate personal protection equipment is essential to ensure safety in the bird management, as well as to avoid prolonged contact, which may cause animal stress and direct contamination. The probability of free-living birds to harbor resistant bacteria increases according to their proximity to anthropogenic centers (Cole et al., 2005), reflecting the use of antibiotics in the region where they are found (Bonnedahl et al., 2009).

Another possibility is the contamination of the artificial nests by secretions of several invasive animals. In addition, the contact with migratory birds, whose ability to reach multiple territories makes them relevant foci of microbial spread is a hypothesis widely advocated in previous studies to explain the primary source of multidrug resistance bacteria in regions far from urban centers (Dolejska et al., 2007). In the Baturité Massif, a survey of the avifauna showed a wide number of avian species, including migratory birds, which supports this hypothesis (Albano \& Girão, 2008). Moreover, it is also possible that the resistance mechanisms of these bacteria were triggered by natural environmental pressure, which promoted the occurrence of strains with such characteristics even in the absence of antimicrobial use (Nascimento et al., 2003).

Whatever the origin of these bacteria in the examined birds, their presence may indicate that greybreasted parakeets may could act as reservoirs of these enteric microorganisms, highlighting the need of further microbiological studies to understand their pathogenicity in these wild birds. Therefore, a health monitoring program of young and adult grey-breasted parakeets would bring a deeper understanding of the epidemiological evolution of their colonization by enterobacteria. In addition, the current study may serve as a first step for further research on the greybreasted parakeet, contributing for its conservation program as well as to emphasize the importance of Brazilian biodiversity.

\section{ACKNOWLEDGMENTS}

The authors thank Conselho Nacional de Desenvolvimento Científico e Tecnológico (CNPq) for their financial support, and Associação de Pesquisa e Preservação de Ecossistemas Aquáticos (AQUASIS) for their support during the sample collection effort.

\section{REFERENCES}

Albano C, Girão W. Aves das matas úmidas das serras de Aratanha, Baturité e Maranguape, Ceará. Revista Brasileira de Ornitologia 2008;16(2):142154

Allgayer MC, Oliveira SJ, Mottin VD, Loiko MR, Neiva FA, Guedes MR, et al. Isolamento de Salmonella Braenderup em arara-azul (Anodothnchus hyacinthius). Ciência Rural 2009;39:2542-2545. 
Machado DN, Lopes ES,

Albuquerque AH, Horn RV,

Bezerra WGA, Siqueira RAS, Lopes IT,

Nunes FP, Teixeira RSC, Cardoso WM

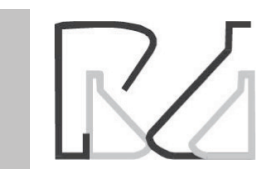

Isolation and Antimicrobial Resistance Profiles
of Enterobacteria from Nestling Grey-Breasted
Parakeets (Pyrrhura Griseipectus)
Alves RRN, Leite RCL, Souto WMS, Bezerra DMM, Loures-Ribeiro A. Ethnoornithology and conservation of wild birds in the semi-arid Caatinga of northeastern Brazil. Journal of Ethnobiology and Ethnomedicine 2013;9(14):1-12

Bangert ABR, Cho APR, Widders AEH, Stauber BD, Ward ACS. A survey of Aerobic Bacteria and Fungi in the Feces of Healthy Psittacine Birds. Avian Diseases 1988;32:46-52.

Beskin $\mathrm{CMH}$, Wilson $\mathrm{K}$, Jones $\mathrm{K}$, Hartley IR. Bacterial pathogens in wild birds:a review of the frequency and effects of infection. Biological Reviews 2009;84(3):349-373.

Bonnedahl J, Drobni M, Gauthier-clerc M, Hernandez J, Granholm S, Kayser Y, et al. Dissemination of Escherichia coli with CTX-M type ESBL between human and yellow-legged gulls in the South of France. PloS One $2009 ; 4(6): 1-6$

Brasil. Portaria do MMA n 444, de 17 de dezembro de 2014. Reconhece como espécies da fauna brasileira ameaçadas de extinção aquelas constantes da "Lista Nacional Oficial de Espécies da Fauna Ameaçadas de Extinção". Diário Oficial da União, Brasília, DF; 17 dez. 2014

Butron O, Brightsmith DJ. Testing for Salmonella spp. In released parrots, wild parrots, and domestic fowl in Lowland Peru. Journal of Wildlife Diseases 2010;46(3):718-729

Carroll D, Wang J, Fanning S, McMahon BJ. Antimicrobial resistance in wildlife: implications for public health. Zoonoses and Public Health 2015;62(7):534-542

Churria DG, Arias N, Origlia J, Netri C, Marcantoni H, Píscopo M, et al. Citrobacter freundii infection in two captive Australian King parrots (Alisterus scapularis). Journal of Zoo and Aquarium Research 2014;2(2):52-53

CLSI - Clinical Laboratory and Standards Institute. Performance standards for antimicrobial susceptibility testing; twenty-second informational supplement [cited 2015 Jul.]. Wayne; 2012. Available from: http://antimicrobianos.com.ar/ATB/wp-content/uploads/2012/11/ MS100S22E.

Cole D, Drum DJV, Stallknecht DE, White DG, Lee MD, Ayers S, et al. Freeliving Canada Geese and antimicrobial resistance. Emerging Infectious Diseases Journal 2005;11(6):935-938.Cruz AT, Cazacu AC, Allen CH. Pantoea agglomerans, a plant pathogen causing human disease. Journal of Clinical Microbiology 2007;45(6):1989-1992

Davies M, Cunha MPV, Oliveira MGX, Oliveira MCV, Philadelpho N, Romeiro DC, et al. Virulence and antimicrobial resistance of Klebsiella pneumoniae isolated from passerines and psittacine birds. Avian Pathology 2016;45(2):194-201.

Delétoile A, Decre D, Courant S, Passet V, Audo J, Grimont P, et al. Phylogeny and identification of Pantoea species and typing of Pantoea agglomerans strains by multilocus gene sequencing. Journal of Clinical Microbiology 2009;47(2):300-310

Dolejska M, Cizek A, Literak I. High prevalence of antimicrobial-resistant genes and integrons in Escherichia coli isolates from Black-headed Gulls in the Czech Republic. Journal of Applied Microbiology 2007;103(1):11-19.

Dongen WFD, White J, Brandl HB, Moodley Y, Merkling T, Leclaire S, et al. Age-related differences in the clocal microbiota of a wild bird species. Ecology 2013;13:11.

Ewers C, Anta EM, Diehl I, Philipp HC, Wieler LH. Intestine and environment of the chicken as reservoirs for Extraintestinal pathogenic Escherichia coli strains with zoonotic potential. Applied Environmental Microbiology 2009;75(1):184-192
Fernandez A, Vela Al, Andrada MA, Herraez P, Díaz-delgado J, Domínguez $L$, et al. Citrobacter freundii septicemia in a stranded newborn cuvier's beaked whale (Ziphius cavirostris). Journal of Wildlife Disease 2011;47(4):1043-1046.

Gerlach H. Bacteria. In: Ritch BW, Harrison GJ, Harrison LR, editors. Avian medicine: principles and application. Lake Worth (FL): Wingers Publishing; 1994. p.948-983

Gibbs PS, Kasa R, Newbrey J, Petermann SR, Wooley RE, Vinson HM, et al. Identification, antimicrobial resistance profiles, and virulence of members from the family Enterobacteriaceae from the feces of yellowheaded blackbirds (Xanthocephalus xanthocephalus) in North Dakota. Avian Diseases 2007;51(3):649-655.

Girão W, Albano C, Campos AA. Inselbergs as habitat to the critically endangered grey-breasted parakeet (Pyrruhura griseipectus), an endemic species from northeastern Brazil. Revista. Brasileira de Ornitologia 2010;18(40):130-132.

Godoy SN. Psittaciformes (arara, papagaio, periquito). In: Cubas ZS, editor Tratado de animais selvagens. São Paulo: Rocca; 2007. p.222-251.

Hasan B, Sandegren L, Melhus A, Drobni M, Hernandez J, Waldenström $J$, et al. Antimicrobial drug-resistant Escherichia coli in wild birds and free-range poultry, Bangladesh. Emerging Infectous Diseases Journal 2012;18(12):2055-2058.

Hidasi HW, Neto HJ, Moraes DM, Linhares GF, Jayme VS, Andrade MA Enterobacterial detection and Escherichia coli antimicrobial resistance in parrots seizes from illegal wildlife trade. Journal of Zoo and Wildlife Medicine 2013:44(10):1-7.

Hirsh, DW, Zee YC .Microbiologia veterinária. Rio de Janeiro: Guanabara Koogan; 2009.

Hu ZG, Pan YS, Wu H, Hu H, Xu R, Liu JH, et al. Prevalence of tetracycline resistance genes and identification of tet $(\mathrm{M})$ in clinical isolates of Escherichia coli from sick ducks in China. Journal of Medical Microbiology 2013;62(6):851-858.

Kohl KD. Diversity and function of the avian gut microbiota. Journal of Comparative Physiology B 2012;182(5):591-602.

Koneman E, Win Jr. W, Allen S, Janda W, Procop G, Schreckenberger P, et al. Diagnóstico microbiológico: texto e atlas colorido. 6th ed. Rio de Janeiro: Guanabara Koogan; 2010.

Lopes ES, Cardoso WM, Albuquerque AH, Teixeira RSC, Salles RPR, Bezerra WG, et al. Isolation of Salmonella spp. em Psittaciformes from zoos and a commercial establishment of Fortaleza, Brazil. Arquivo Brasileiro de Medicina Veterinária e Zootecnia 2014;66(3):965-969

Lopes ES, Maciel WC, Albuquerque AH, Machado DN, Bezerra WGA Vasconcelos $\mathrm{RH}$, et al.. Prevalence and antimicrobial resistance profile of enterobacteria isolated from Psittaciformes of illegal wildlife trade. Acta Scientiae Veterinariae 2015;43:1313

Machado DN, Lopes ES, Albuquerque ÁH, Bezerra WGA, Horn RV, Lima SVG et al. Detecção e avaliação do perfil de sensibilidade antimicrobiana de enterobactérias isoladas de periquitos cara-suja (Pyrrhura griseipectus) em cativeiro. Arquivo Brasileiro de Medicina Veterinária e Zootecnia 2016:68(6):1732-1736.

Marietto-Gonçalves GA, Almeida SM, Lima ET, Andreatti Filho RL. Detecção de Escherichia coli e Salmonella spp. em microbiota intestinal de Psittaciformes em fase de reabilitação para soltura. Brazilian Journal of Veterinary Research and Animal Science 2010;47(3):185-189.

Marietto-Gonçalves GA, Almeida SM, Lima ET, Okamoto S, Oinczowski $\mathrm{P}$, Filho RLA. Isolation of Salmonella enterica serovar Enteritidis in Blue-Fronted Amazon Parrot (Amazona aestiva). Avian Diseases 2010;54:151-155 
Machado DN, Lopes ES,

Albuquerque AH, Horn RV,

Bezerra WGA, Siqueira RAS, Lopes IT,

Nunes FP, Teixeira RSC, Cardoso WM

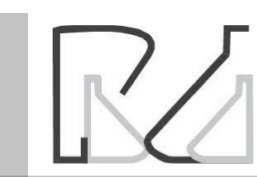

Isolation and Antimicrobial Resistance Profiles of Enterobacteria from Nestling Grey-Breasted Parakeets (Pyrrhura Griseipectus)
Marietto-Gonçalves GA, Lima GA, Sequeira JL, Andreatti Filho RL. Colisepticemia em Papagaio verdadeiro (Amazona aestiva). Revista Brasileira de Saúde e Produção Animal 2007;8(1):56-60.

Mattes BR, Consiglio AS, Almeida BZ, Guido MC, Orsi RB, Da silva RM, et al. Influência da biossegurança na colonização intestinal por Escherichia coli em psitacídeos. Arquivos do Instituto Biológico 2005;72(1):13-16.

Mills TK, Lombardo MP, Thorpe PA. Microbial colonization of the cloacal of nestling tree swallows. The Auk 1999;116(4):947-956.

Mitchell, M.A. Azithromycin. Seminars in Avian Exotic Pet Medicine Journal 2005;14(1):212-214

Naldo JL, Silvanose CD, Samour JH, Bailey TA. Developmental intestinal aerobic microflora in the Kori bustard (Ardeotis kori). Avian Pathology 1988;27(4):359-365.

Nascimento AMA, Cursino L, Gonçalves-Dornelas H, Reis A, ChartoneSouza E, Marini M.A. Antibiotic-resistant Gram-negative bacteria in birds from the brazilian atlantic forest. The Condor 2003;105(2):358361.

Nascimento FR, Souza MJN, Cruz MLN. Diagnóstico socioeconômico da área de proteção ambiental da Serra de Baturité-Ceará. Ra'Ega 2010;20:19-33.

Olinda RG, Souza MCA, Figueiredo JN, Silva JMC, Alves ND, Bezerra FSB, et al. Diagnosis of Proteus spp. in wild birds raised under captivity in Rio Grande do Norte, Brazil. Arquivos do Instituto Biológico 2012;79(2):301-303.

Prioste FES, Cunha MPV, Teixeira RHF, Zwargg T, Di-chiacchio RG, Melville PA, et al. Genetic similarity between APEC and Escherichia coli strains isolated from Guaruba guarouba in a survey on healthy captive psittacine birds. Brazil Journal of Veterinay Research and Animal Science 2013;50(2):145-151.

Radhouani H, Poeta P, Gonçalves A, Pacheco R, Sargo R, Igrejas G. Wild birds as biological indicators of environmental pollution:antimicrobial resistance patterns of Escherichia coli and enterococci isolated from common buzzards (Buteo buteo). Journal of Medical Microbiology 2012;61(6):837-843.
Saidenberg AB, Teixeira RHF, Guedes NMR, Allgayer MC, Melville PA, Benites NR. Molecular detection of enteropathogenic Escherichia coli in asymptomatic captive psittacines. Pesquisa Veterinária Brasileira 2012;32(9):922-926.

Santos HF, Flôres ML, Lara VM, Silva MS, Battisti L, Lovato LT. Microbiota clocal aeróbia de cracídeos cativos no Rio Grande do Sul e sua susceptibilidade a antimicrobianos. Pesquisa Veterinária Brasileira 2010;30(12):1077-1082.

Schremmer C, Lohr JE, Wasthulber U, Kösters J, Ravelshofer K, Steinrück $\mathrm{H}$, et al. Enteropatogenic Escherichia coli in Psittaciformes. Avian Pathology 1999;28(4):349-354.

Serafini PP, Meurer R, Biesdorf SM, Sipinski EAB. O uso da microbiologia como ferramenta para a conservação de aves ameaçadas:dados preliminares para o papagaio-de-cara-roxa, Amazona brasiliensis (Aves:Psittacidae) no Paraná. Arquivos de Ciências Veterinárias e Zoologia da UNIPAR 2015;18(1):65-69.

Sigrist T. Avifauna brasileira. São Paulo: Avis Brasilis; 2014.

Sjølund M, Bonnedahl J, Hernandez J, Stina B, Cederbrant G, Pinhassi $J$, et al. Dissemination of multidrug-resistant bacteria into the Artic. Emerging Infectious Diseases 2008;14(1):70-72.

Smith S, Wang J, Fanning S, McMahon BJ. Antimicrobial resistant bacteria in wild mammals and birds: a coincidence or cause of concern? Irish Veterinary Journal 2014;67(8):1-3.

Szmolka A, Nagy B. Multidrug resistant commensal Escherichia coli in animals and its impact for public health. Frontiers in Microbiology 2013;4:1-13.

Tortora GJ, Funke BR, Case CL. Microbiologia. 10th ed. Porto Alegre: Artmed; 2012.

Vaz FF, Serafini PP, Locatelli-Dittrich R, Meurer R, Durigon EL, Araújo J, et al. Survey of pathogens in threatened wild red-tailed Amazon parrot (Amazona brasiliensis) nestlings in Rasa Island, Brazil. Brazilian Journal of Microbiology 2017;48(4):747-753. 